\title{
Heatwaves and health: reflections on the El Niño phenomenon in Piura, Peru
}

\author{
Golpes de calor y salud: reflexiones a propósito \\ del fenómeno El Niño en Piura, Perú
}

\author{
Ondas de calor e saúde: reflexões sobre o \\ fenômeno El Niño em Piura, Peru
}

1 Sociedad Científica de Estudiantes de Medicina, Universidad Privada Antenor Orrego, Trujillo, Perú.

2 Sociedad Científica de Estudiantes de Medicina Universidad Nacional de Piura, Piura, Perú.

Correspondence

P. Aguilar-León

Sociedad Científica de

Estudiantes de Medicina

Universidad Privada Antenor Orrego.

Av. América Sur 3145, Trujillo

1075, Trujillo / La Libertad -

13001, Perú.

paguilarl@upao.edu.pe
The report of eight deaths of children less two years of age, in early March 2016, in Piura, a region in the North of Peru, has called the attention of health authorities, who have attributed the deaths to high temperatures associated with the El Niño-Southern Oscillation (ENSO). All the children presented hyperthermia, diarrhea, dehydration, and seizures, with a fatal outcome despite rigorous treatment and life support measures. The hypothesis raised by local attending physicians indicates a heatwave as the principal cause of the deaths 1 .

This position is based partly on the high temperatures reported by the Peruvian Nacional Meteorology and Hydrology Service (SENAMHI), exceeding $35^{\circ} \mathrm{C}$ and with the heat index reaching a peak of $46^{\circ} \mathrm{C} 2$.

In Peru, ENSO affects people differently according to demographics; on the Northern Coast, which includes Piura, it increases the ocean and surface water temperatures, leading to major evaporation that extends across the Andes, causing persistent rains, unlike the Southern Sierra, where drought prevails, protected by a layer of dry air that blocks the entry of easterly winds. The effects of ENSO in 1997-1998 in Piura consisted of floods, damage to infrastructure and transportation, crop destruction, and deaths 3 , besides favoring various pests due to changes in the ecosystem; SuárezOgnio et al. 4 had already warned of the presence of "heatwaves" in the context of El Niño, a
Pool Aguilar-León 1

Fiorela Solano-Zapata ${ }^{2}$

relationship seen in the impact on the Peruvian Coast in 1998

Heatwaves, or simply periods of extreme heat, generally emerge as extreme temperatures exceeding the 95th percentile and sustained for two or more days, with repercussions on human health 5 . Heatwaves are currently considered an emerging public health problem, with evidence based on the high mortality recorded during such phenomena in Chicago (USA) in 1995, Europe in 2003, and Russia in 20106.

The pathophysiology involves disturbance of the body's own thermal regulation, which decreases the sweating rate. Sweating allows cooling the body in relation to ordinary temperature, but if the temperature increases, sweat is excreted more slowly, preventing the body from cooling adequately; thus, when $40^{\circ} \mathrm{C}$ is reached, organ damage begins 7 . According to pediatric experts, this direct compromise can even lead to altered level of consciousness ${ }^{8}$.

Overheating in infants can lead to dehydration and associated manifestations such as exhaustion, cramps, fainting, edema, and fever. When severe dehydration occurs it causes acute stroke, clot formation, aggravation of chronic lung conditions, cardiac complications, renal dysfunction, and psychiatric disorders. The pathophysiology lies in dehydration, which decreases the sweating rate; this is a common cause of hyperthermia and death in both age extremes, that is, in children under four years (especially 
infants) and in older adults or those with cognitive decline who require someone else to help them ingest adequate amounts of liquid 5 . Severe cases can lead to hyperthermia and death 9 . This is because children under four years are highly vulnerable to climate change given the immaturity of the regulatory mechanisms, greater energy consumption, which generates more heat, and minimal body surface; and greater generation of heat due to metabolic expenditure and their small body surface ${ }^{8}$.

As we have seen, the cause of infant deaths suggests climate effects in Piura, where temperatures exceeded $40^{\circ} \mathrm{C}$ in the early months of 2016 , even reaching $46^{\circ} \mathrm{C}$. In November the problem had already been elucidated, with abnormal ocean temperatures greater than $+4^{\circ} \mathrm{C}$ in Paita, one of the main ports in Piura, abnormalities that had not been seen as drastically in previous ENSOs, reaching $+2^{\circ} 8,10$.

According to the last report by the Intergovernmental Panel on Climate Change (IPCC), heatwaves will increase in frequency due to global warming ${ }^{11}$. This situation is alarming for Peru, the third country most exposed to risk of consequences of climate change, which should launch the search for new forms of adaptation to future changes related to heatwaves 12 .

\section{Contributors}

P. Aguilar-León and F. Solano-Zapata made substantial contributions to the article's concept; participated in writing the manuscript and critical revision, contributing to its intellectual content; and approved the final version.
One solution to the future problem is the implementation of a Heat Health Warning System (HHWS), deployed in other countries such as Australia. HHWSs are designed to warn people of the imminent danger of heat, besides serving as a source of advice on how to avoid adverse health outcomes. Identification of the vulnerable population, interaction with various stakeholders, design and deployment of intervention strategies, application of long-term heat mitigation procedures, and public awareness-raising and urban planning are the system's components. HHWSs can thus be seen as an important strategy for adaptation that can help mitigate the impacts of future heatwaves 13 . Thus far there is no indication that Peru wants such a system. The document National Strategy on Climate Change of the Peruvian Ministry of the Environment contains no measures or concrete proposals to deal with heatwaves in light of the country's climatic vulnerability, given recognition of the application of weather services as a health sector priority 14 .

Given the above, it is essential to include measures to deal with heatwaves when planning health and environmental strategies, including the deployment of a HHWS as an excellent initiative by government, including other institutions such as SENAMHI, social services, and the health sector. Importantly, the ENSO phenomenon and its unfortunate consequences are merely a warning of something much bigger that merit merits immediate and careful attention. 
1. Zapata R. Piura: consideran que golpe de calor provocó muerte de 8 niños. El Comercio 2016; 2 mar. http://elcomercio.pe/peru/piura/conside ran-que-golpe-calor-causo-muerte-8-ninos-piu ra-noticia-1883329.

2. Zapata R. Piura llegó a registrar una sensación térmica de 46 grados. El Comercio 2016; 4 mar. http:// elcomercio.pe/peru/piura/piura-llego-registrarsensacion-termica-46-grados-noticia-1884083.

3. Oficina de Defensa Nacional, Ministerio de Salud del Perú; Organización Panamericana de la Salud. El fenómeno El Niño 1997-1998 en Perú. In: Organización Panamericana de la Salud, editor. Crónicas de desastres fenómeno El Niño 1997-1998. Washington DC: Organización Panamericana de la Salud; 2000. p. 232-89.

4. Suárez-Ognio L, Estela-Ayamamani D, CáceresMejía B, Gambirazio-Carbajal C, Cabrera R. Impacto del fenómeno "El Niño" de 1997-1998 en la salud de la población peruana, riesgo potencial para el 2015. Rev Peru Med Exp Salud Pública 2015; 32:403-4.

5. Xu Z, FitzGerald G, Guo Y, Jalaludin B, Tong S. Impact of heatwave on mortality under different heatwave definitions: a systematic review and meta-analysis. Environ Int 2016; 89-90:193-203.

6. Green H, Andrews N, Armstrong B, Bickler G, Pebody R. Mortality during the 2013 heatwave in England: how did it compare to previous heatwaves? A retrospective observational study. Environ Res 2016; 147:343-9.

7. Hospital Cayetano Heredia, Ministerio de Salud. Golpe de calor. Boletín Epidemiológico 2016; (03). http://www.hospitalcayetano.gob.pe/Inicio/ima ges/Documentos/Epidemio/VOLUMEN3BOLETI NEPIDEMIOLOGICO.pdf.
8. Belletich E. El 'golpe de calor': el peligro no ha pasado. http://udep.edu.pe/hoy/2016/el-golpe-decalor-el-peligro-no-ha-pasado/ (accessed on 20/ Jun/2016).

9. Hajat S, O'Connor M, Kosatsky T. Health effects of hot weather: from awareness of risk factors to effective health protection. Lancet 2010; 375:856-63.

10. Belletich E. La anomalía de la temperatura del mar en Paita llega a $+4^{\circ} \mathrm{C}$. http://udep.edu. pe/hoy/2015/la-anomalia-de-la-temperaturadel-mar-en-paita-llega-a-4c/ (accessed on 20/ Jun/2016).

11. Woodward A, Smith K, Campbell-Lendrum D, Chadee D, Honda Y, Haines A, et al. Climate change and health: on the latest IPCC report. Lancet 2014; 383:1185-9.

12. Wood R, Gilbert P, Sharmina M, Anderson K, Footitt A, Glynn S, et al. Shale gas: a provisional assessment of climate change and environmental impacts. Manchester: Tyndall Center, University of Manchester; 2011.

13. Bassil K, Cole D. Effectiveness of public health interventions in reducing morbidity and mortality during heat episodes: a structured review. Int J Environ Res Public Health 2010; 7:991-1001.

14. Ministerio de Ambiente del Perú. Estrategia nacional ante el cambio climático. Lima: Fondo Editorial del MINAM; 2015.
Submitted on 21/Mar/2016

Final version resubmitted on 19/Aug/2016

Approved on 08/Sep/2016 